\title{
Study on the Influence of Foreign Direct Investment on the Optimization of Trade Structure
}

\author{
Xuejie Zhao \\ Business School, Hohai University, Nanjing, China \\ Email: 2516191892@qq.com
}

How to cite this paper: Zhao, X.J. (2019) Study on the Influence of Foreign Direct Investment on the Optimization of Trade Structure. Open Access Library Journal, 6: e5316.

https://doi.org/10.4236/oalib.1105316

Received: March 6, 2019

Accepted: March 25, 2019

Published: March 28, 2019

Copyright $\odot 2019$ by author(s) and Open Access Library Inc.

This work is licensed under the Creative Commons Attribution International License (CC BY 4.0).

http://creativecommons.org/licenses/by/4.0/

\section{(c) (i) Open Access}

\begin{abstract}
At present, China is the second largest economy in the world, which plays an important role in both foreign direct investment (OFDI) and import and export trade. Both of them are also very important to the economic development of our country. With the spread of international trade protectionism, China's trade structure needs to be optimized to improve its competitiveness. Based on the present situation of China's OFDI and trade structure, this paper analyzes the influence of OFDI on the optimization of foreign direct investment.
\end{abstract}

\section{Subject Areas}

Business Analysis, Economics

\section{Keywords}

Foreign Direct Investment (OFDI), Trade Structure, Optimize

\section{Current Situation of OFDI}

From the perspective of investment scale: In the face of a weak recovery in the world economy and a decline in outward direct investment in 2016, Chinese enterprises invested 183 billion dollars in overseas direct investment, rising $44 \%$ compared with the same period last year. China has become the world's second-largest outbound investor and has entered the ranks of net capital exporters for the second year in a row. According to CCG data, after China's direct investment in the United States exceeded that of the United States for the first time in 2015, in 2016 Chinese enterprises again outinvested the United States in China. In 2016, Chinese companies invested in 156 US investments, with a total 
investment of US\$ 85.016 billion, a year-on-year increase of 76\%. Trade frictions between China and the United States have an important impact on China's foreign direct investment. According to data from global law firm Baker McKenzie and research firm Rhodium Group: In the first half of 2018, the direction of China's foreign direct investment is shifting from North America to Europe. Recently, China's M\&A value in Europe is nine times that of North America, and its investment in Europe has been six times that of the United States. In terms of investment structure, according to data from the 2017 Statistical Bulletin of China's Outward Foreign Direct Investment, 79.8\% of China's foreign direct investment stock is distributed in the tertiary industry (that is, the service sector), with an amount of US $\$ 1.44393$ trillion, mainly in rental and business services, finance, wholesale and retail, information technology services, real estate and other areas. The secondary sector accounted for $\$ 353.32$ billion, or 19.5 percent of China's foreign direct investment stock, while the primary industry accounted for $\$ 11.79$ billion, or just 0.7 percent of China's outward direct investment stock. The continuous development of foreign direct investment (FDI) shows the development trend of our country's economy from the side. Against the background of the slowing growth of world economy and the prevalence of trade protectionism, the international pressure on China's economic development lacks the impetus to be alleviated. In this complex and changeable environment, if China wants to make progress in its development, it needs to fully coordinate both domestic and international resources and two markets. On the one hand, we should deepen the exchanges and cooperation with the developed countries, strengthen the development of emerging markets and cope with the protectionism of international trade; on the other hand, accelerate the development of external direct investment, actively participate in the global resource allocation, improve the utilization efficiency of the resources and promote the integration of trade and investment.

Therefore, comprehensively and systematically studying the impact mechanism of foreign direct investment on China's trade structure and promoting the coordinated development of foreign trade and investment are of great significance for building an open economic development model and enhancing China's participation in the international division of labor and international competitiveness.

\section{The Influence of Foreign Direct Investment on the Optimization of Trade Structure}

From the point of view of investment target, OFDI can be divided into four types: market-oriented, resource-oriented, efficiency-oriented and technology-oriented [1].

\subsection{Market Oriented OFDI}

The choice of market-oriented OFDI is mainly for two purposes: one is to avoid trade protection and breakthrough trade barriers, the other is to get closer to the 
market, to increase market share or to open up new markets. Enterprises invest in foreign direct investment, investing in foreign factories to produce and sell products originally used for export, which greatly shortens the market distance, replaces the export of some existing products, and produces export substitution effects. Further, this provides more space for the development of other industries. From the perspective of other supervisions, the market-oriented OFDI has expanded the demand for domestic equipment, services and intermediate products, and promoted the export of related domestic products, resulting in a trade creation effect.

\subsection{Resource Oriented OFDI}

The purpose of resource-oriented OFDI is to find scarce resources to meet production while mitigating the adverse effects of price fluctuations. For example, in the direct investment of foreign oil, in this investment process, the enterprise will input some necessary domestic mining equipment, labor and other resources to the host country. This has greatly alleviated the shortage of domestic resources, and solved the bottleneck problem faced by enterprises, so that enterprises can better integrate resources and create conditions for the improvement of technology level [2]. From the aspect of spillover effect, the technology of the host country will inevitably have an impact on the enterprise, which will drive the improvement of the technological level of the enterprise and promote the upgrading of production.

\subsection{Efficiency Oriented OFDI}

Efficiency-oriented OFDI appears after market-oriented and resource-oriented. Its purpose is to improve the efficiency of the use of production factors and optimize the allocation of resources. Generally, through the establishment of branches or subsidiaries, to obtain the required strategic resources, to achieve the pursuit of economies of scale and scope, and to enhance the company's core competitiveness [3]. In addition, according to Kojima's theory of marginal industry transfer and Vernon's product life cycle theory, the transfer of marginal industries that are already in or about to be in a disadvantaged position in China is of great significance for releasing production resources, extending the product life cycle, and promoting enterprise transformation [4].

\subsection{Strategic Asset Oriented OFDI}

The main ways of strategic asset-oriented OFDI are cross-border mergers and acquisitions, establishment of branches, etc. Its purpose is to obtain key resources, gain monopoly advantage, and improve core competitiveness. Strategic assets here mainly refer to advanced technology, scientific management, marketing channels, advanced experience and high-quality personnel. The target of this kind of investment is mainly developed countries. While acquiring strategic assets, the trade structure of home country is optimized through various effects. 
Strategic asset-oriented OFDI breaks the technology blockade and moves strategic assets inward through spillover effects. Then the competitiveness of a certain enterprise, driven by the interests of other enterprises to improve their own, and then promote the entire industry, industry growth [5].

\section{Suggestions on the Better Promotion of the Optimization of the Trade Structure in the Foreign Direct Investment}

From the above discussion, we can see that the mechanism of OFDI promoting trade structure optimization has three main aspects: the flow of factors of production, the level of production technology, and the industrial institutions [1]. Through these three aspects of transmission, the trade structure is optimized. According to the above analysis, this paper takes both government and enterprise as the starting point, and puts forward some development suggestions.

\subsection{Government}

- Adhere to the enterprise as the main body and build a service-oriented government. "According to the principles of market-oriented and independent decision-making, guiding enterprises of all kinds of ownership to invest overseas in an orderly manner" is a clear requirement set out in the $12^{\text {th }}$ five-year Plan. In the critical period of the $13^{\text {th }}$ five-year Plan and building a well-off society in an all-round way, it is still necessary to implement this requirement [6]. Government is the main body of macro-control and plays an important role in supervising and guiding the process and direction of optimizing trade structure. However, the enterprise is the micro-level market subject. In the process of optimizing the trade structure, we should give full play to the role of enterprises and the market, release the vitality of the market, and strengthen the autonomy of the foreign direct investment of enterprises. At the same time, the government should improve its service ability, build a service-oriented government, and play a good role in guiding, serving and supervising in the process of optimizing the trade structure. It is also necessary for the government to formulate practical policies to promote foreign direct investment and optimize the trade structure.

- Improve the construction of the legal system and increase policy support. At present, China's legislation on "going out" obviously lags behind the requirements of the development of enterprises. The laws and regulations of foreign direct investment are not perfect and imperfect, and the legislative level is low [6]. The foreign direct investment of enterprises is lack of legal protection. The lag of laws and regulations restricts the foreign direct investment behavior of enterprises. Based on the requirements of economic development and the optimization of trade structure, the government should proceed from the reality and draw on advanced appropriate international regulations and management experience to improve the corresponding domestic laws and regulations. In addition, the government will also increase 
the policy support for foreign direct investment of enterprises. On the one hand, the government should provide strong fiscal and tax support policy to the enterprises that carry on the outward direct investment. For example, for some enterprises that engage in high-level foreign direct investment, policies such as tax reduction or deferred tax payment are provided to reduce the tax burden of enterprises. Moreover, the government should also provide preferential financial policy support to OFDI enterprises. At present, corporate credit costs are high and auditing is difficult. The government should appropriately increase export credit support, moderately reduce corporate financing interest rates, gradually liberalize multinational corporations' overseas financing and financing rights, and guide financial institutions to increase their foreign direct investment. Financial Services.

- Actively participate in the development of global investment rules. Economic globalization is an irresistible trend, China should gradually improve the right to speak on the international stage. Our government should actively participate in bilateral and multilateral economic and trade activities, abide by international investment rules, at the same time participate in the formulation of international investment rules, safeguard China's legitimate rights and interests, and promote the improvement of equity in foreign investment. The improvement of participation in rule-making is of great significance to the improvement of foreign investment environment of Chinese enterprises. In addition to the active participation of the government in the formulation of the rules, the government also encourages Chinese enterprises to actively participate in the international association and strengthen their understanding of the international rules.

\subsection{Enterprises}

- Actively participate in global competition. Foreign direct investment (FDI) is a two-way interactive process between domestic enterprises and the international market. With the further development of economic globalization and industrial revolution, the international division of labor and value creation system are undergoing profound changes. This is an opportunity and a challenge. In this context, the opening of the production chain and value chain has been improved unprecedented. Enterprises should seize this opportunity, promote the transformation and upgrading of enterprises, and continue to climb to high value-added links. Under the tide of economic globalization, if enterprises cannot actively participate in international competition, they will one day be carried into globalization passively. Therefore, enterprises should improve themselves, seize the first opportunity of international market, make full use of domestic and international resources and two markets.

- Establishing modern enterprise system. OFDI mainly includes new investment, cross-border M \& A and strategic alliance. Enterprises should choose the appropriate form of OFDI. In view of this, the advantages of modern en- 
terprise system are highlighted. The modern enterprise system with clear property rights and clear rights and responsibilities makes it possible for foreign direct investment enterprises to better deal with the relationship between home companies and multinational corporations [6]. At the same time, the restriction and incentive system, informatization and scientific decision-making system of modern enterprises are also more perfect. This plays a key role in improving the core competitiveness of enterprises and promoting the long-term development of enterprises.

- Improve Innovation ability, introduce and cultivate High-quality talents. Innovation is the driving force for the continuous development of enterprises. Enterprises should strengthen financial support for technological innovation and scientific research. At the same time, it is necessary to arouse the enthusiasm of scientific research personnel to create innovation, such as carrying out joint-stock reform of enterprises and rewarding scientific and technological personnel with shares, so that enterprise personnel can fully participate in all aspects of enterprise production and management. In addition, enterprises should actively introduce and cultivate high-quality international talents. No matter the production creation or the management cannot leave the talented person. For outward direct investment, participating in international competition of enterprises, talent is more important. In foreign investment, the feasibility of investment should be fully considered, which requires enterprises to have a full understanding of the local culture, legal system and policy environment. As a result, high-quality international talents are particularly important.

\section{Conclusion}

As far as enterprises are concerned, FDI is an important step for enterprises to go to the world stage and realize internationalization, and it is also the key to the transformation and upgrading of enterprises. From the comparative advantage theory, technology localization theory and other foreign direct investment theories, it can be seen that the structure of trade and foreign direct investment are inextricably related. Through the above analysis, we can see that the optimization of foreign direct investment and trade structure involves both countries and enterprises, which is of great significance to both sides. Therefore, with the continuous advancement of economic globalization and the deepening of the industrial revolution, the optimization of FDI and trade structure requires the joint efforts of both countries and enterprises.

\section{Conflicts of Interest}

The author declares no conflicts of interest regarding the publication of this paper.

\section{References}

[1] Hu, W.X. (2015) The Influence of China's Outward Direct Investment on the Op- 
timization of Export Trade Structure. Journal of Wuhan Communications Vocational College, 17, 16-20+25.

[2] Han, L. (2015) The Analysis of China to US Direct Investment's Impact on the Commodity Structure between China and US Commodity Trade. Master's Thesis, Dalian Maritime University, Dalian.

[3] Xu, X.Q, (2017) Study on the Influence of China's OFDI to Industrial Upgrading. PhD Thesis, Jilin University, Changchun.

[4] Zhou, Y.J. (2015) A Study on the Impact of China's Foreign Direct Investment on the Upgrading of Domestic Industry. Master's Thesis, Anhui University of Finance, Hefei.

[5] Fang, Y. (2015) The Impact of China's Foreign Direct Investment on the Upgrading of Domestic Industry and Its Countermeasures. Gansu Social Science, No. 3, 156-160.

[6] Yu, F. (2013) Study on the Industrial Upgrading Effect of China's Foreign Direct Investment. PhD Thesis, Graduate School of Chinese Academy of Social Sciences, Beijing. 